\title{
Determinants of health behaviors in individuals of medical and non-medical professions
}

\section{Grzegorz Józef Nowicki', Barbara Ślusarska', Ewa Rudnicka-Drożak², Anna Wiśniewska', Bernadeta Jędrzejkiewicz' ${ }^{1}$ Kamil Pielaszkiewicz ${ }^{3}$, Aleksandra Sekut ${ }^{4}$}

ZZakład Medycyny Rodzinnej i Pielęgniarstwa Środowiskowego, Wydział Nauk o Zdrowiu, Uniwersytet Medyczny w Lublinie /Department of Family Medicine and Community Nursing, Faculty of Health Sciences, Medical University of Lublin

${ }^{2}$ Katedra i Zakład Medycyny Rodzinnej, I Wydział Lekarski Uniwersytet Medyczny w Lublinie /Chair and Department of Family Medicine, I Faculty of Medicine with Dentistry Division, Medical University of Lublin

II Katedra i Klinika Chirurgii Ogólnej, Gastroenterologicznej i Nowotworów Układu Pokarmowego, I Wydział Lekarski, Uniwersytet Medyczny w Lublinie /II Chair and Department of General and Gastrointestinal Surgery and Surgical Oncology of the Alimentary Tract,

I Faculty of Medicine with Dentistry Division, Medical University of Lublin ${ }^{4}$ Studentka III roku kierunku pielegniarstwo, Wydział Nauk o Zdrowiu, Uniwersytet Medyczny w Lublinie /Student of the 3rd year of nursing, Faculty of Health Sciences, Medical University of Lublin

\section{AUTOR KORESPONDENCYJNY/CORRESPONDING AUTHOR: \\ Grzegorz Józef Nowicki \\ Zakład Medycyny Rodzinnej i Pielęgniarstwa Środowiskowego, Wydział Nauk o Zdrowiu Uniwersytetu Medycznego w Lublinie \\ ul. Staszica 6, 20-081 Lublin \\ tel. +48814486810 \\ e-mail: grzesiek_nowicki@interia.pl}

\section{STRESZCZENIE}

Słowa kluczowe:
DETERMINANUY ZACHOWAŃ ZDROWOTNYCH OSÓB WYKONUJACYCH ZAWODY MEDYCZNE I POZAMEDYCZNE

Cel pracy. Określenie determinantów zachowań zdrowotnych w grupie osób wykonujących zawody medyczne i pozamedyczne.

Materiał i metodyka. Badaniami objęto 598 podzielonych na dwie grupy: osób wykonujących zawody medyczne (grupa M; $\mathrm{n}=305$ ) i pozamedyczne (grupa $P ; n=293$ ). Użyto narzędzi standaryzowanych: Inwentarza Zachowań Zdrowotnych, Wielowymiarowej Skali Umiejscowienia Kontroli Zdrowia - wersja B, Skali Uogólnionej Własnej Skuteczności oraz Testu wiedzy na temat czynników ryzyka i profilaktyki chorób cywilizacyjnych (własnego autorstwa). Badanym wykonano pomiar ciśnienia tętniczego krwi oraz wzrostu i masy ciała.

Wyniki. W grupie M. poziom własnej skuteczności, umiejscowienie kontroli zdrowia w kategoriach wpływ innych i przypadek, wiek występowanie chorób układu krążenia u ojca, palenie papierosów oraz poziom średniego ciśnienia skurczowego wyjaśniają 17,5\% zmienności zachowania zdrowotnego. W grupie P poziom własnej skuteczności, umiejscowienie kontroli zdrowia w kategorii wpływ innych i przypadek, miesięczny dochód netto na członka rodziny, występowanie nowotworów u rodzeństwa, palenie papierosów, średnia wartość ciśnienia tętniczego krwi oraz poziom wiedzy o czynnikach ryzyka i profilaktyce chorób cywilizacyjnych wyjaśniają 27,9\% wariancji zmiennej zachowania zdrowotne.

Wnioski. Istnieje zróżnicowanie wybranych uwarunkowań zachowań zdrowotnych w grupie osób wykonujących zawody medyczne i pozamedyczne, z silniejszym ich wpływem dla osób pracujących w zawodach pozamedycznych (17,5\% vs. 27,9\% ich zmienności). zachowania zdrowotne, osoby pracujące, determinanty

DETERMINANTS OF HEALTH BEHAVIORS IN INDIVIDUALS OF MEDICAL AND NON-MEDICAL PROFESSIONS

Aim. Determination of health behaviors in the group of people performing medical and non-medical professions.

Material and methods. The research covered 598 individuals divided into two groups: those performing medical professions (group M, $\mathrm{n}=305$ ) and non-medical (group P; $\mathrm{n}=293$ ). Standardized tools were used: Health Behavior Inventory, Multidimensional Health Locus of Control Scale - version B, General Self-Efficacy Scale on risk factors and prevention of civilization diseases (own authorship). The controls were subjected to measurement of blood pressure as well as their height and body mass tests.

Results. In group M, the level of self-efficacy, the location of health control in terms of the influence of the others and the chance, age, incidence of cardiovascular diseases in the father, smoking and the level of mean systolic blood pressure explain $17.5 \%$ of the variability of health behavior. In group $P$, the level of self-efficacy, location of health control in terms of the influence of the others and the chance, monthly net income per a family member, the occurrence of neoplasms in siblings, smoking, average blood pressure and 
the level of knowledge about risk factors and prevention of civilization diseases explain $27.9 \%$ of the variance of the health behavior variable.

Conclusions. There is a diversification of selected determinants of health behaviors in the group of individuals performing medical and non-medical professions, with their stronger impact on non-medical professionals ( $17.5 \%$ vs. $27.9 \%$ of their variability).

Key words: health behaviors, working individuals, determinants

\section{INTRODUCTION}

Maintaining good health and detecting its disorders is determined by the health behaviors of the individual and taking independent actions to control and evaluate the functioning of the body. Health behaviors and their determinants are the focus of many fields of social and medical sciences. Thanks to empirical analyzes of health behaviors and their conditions through the prism of various academic fields, resulting from a separate scientific workshop and the experience of a given field, research results and theoretical considerations bring a new light into the multidimensional perception of this issue [1].

Professional work is one of the main forms of human activity. The workplace is a perfect place to implement various promotional projects in the sphere of health, especially in the field of changing anti-health behaviors. Combining health with lifestyle requires providing the individual with the help to introduce modifications of individual behavior patterns and shape a pro-health lifestyle based on conscious undertaking of specific activities that increase the resources of one's own health and eliminate threats. A key role in this process is attributed to predictors of health behaviors [2].

\section{AIM}

The aim of the study is to determine predictors of health behavior types in individuals of medical and non-medical professions.

\section{MATERIALS AND METHODS}

The study was carried out from June 2014 to March 2015. As many as 598 professionally active individuals, representatives of 6 professions, including 3 medical professions (group M) - 305 individuals and 3 non-medical professions (group P) - 293 individuals participated in them. Group $M$ was represented by nurses and midwives $(61.97 \% ; \mathrm{n}=189)$, medical caregivers $(16.2 \% ; \mathrm{n}=51)$ and medical sterilization technicians $(21.31 \% ; \mathrm{n}=65)$. The P group included: miners $(42.66 \% ; \mathrm{n}=125)$, teachers $(34.13 \%)$ and prison staff $(34.13 \% ; \mathrm{n}=100)$.

The study method was a diagnostic survey and a double measurement of blood pressure, height and body mass in order to calculate the BMI index. The questionnaire consisted of the following research tools: particulars (evaluating socio-demographic data), Health Behavior Inventory - HBI (assessing health behaviors in terms of: healthy eating habits, preventive measures, health practices and positive mental attitude, as well as a general level of health behaviors), Multidimensional Health Locus of Control Scale - MHLC - version B (captures beliefs concerning generalized expectations in three dimensions of health locus of control, i.e. internal ones, influence of others and chance), Generalized Self-Efficacy Scale - GSES (to measure the general assurance of the individual in relation to the effectiveness of coping with difficult situations and obstacles) [3]. Knowledge test (own authorship) on the risk factors and prevention of civilization diseases included 25 questions, of which the first 15 were common for both genders, and the last 10 questions were different for males and females. The tool aimed to evaluate the level of knowledge about nationwide prevention programs, knowledge of the principles of breast and testes self-examination and risk factors of the most common civilization diseases. A true-false test was used to determine whether the given statements were true or false. The obtained responses were scored - the respondent received 1 point for the correct answer, and 0 - for the incorrect or no answer. The maximum score for the respondent to gain was 25 points. The higher the score, the deeper the respondent's knowledge.

Body mass was measured using the clinic scales accurate to within $0.1 \mathrm{~kg}$. The height was determined by means of an altimeter accurate to within $0.5 \mathrm{~cm}$. Then, the BMI index, defined as body mass in kilograms ( $\mathrm{kg}$ ) divided by the height in square meters $(\mathrm{kg} / \mathrm{m} 2)$ [4] was calculated for all controls. The resting blood pressure measurement was performed by means of Korotkov method. The measurement was performed twice. An OMRON M1 electronic sphygmomanometer was applied for the purpose.

The obtained results were subjected to statistical analysis. The values for the analyzed measurable parameters were presented using the mean value, standard deviation, the minimum and maximum values as well as the median, and for non-measurable ones - by means of the numerosity and the percentage. The distribution of the analyzed variables was checked by means of the Shapiro-Wilk test. In order to examine differences in measurable parameters between the two groups, the Student's t-test was used. A stepwise regression analysis was applied to evaluate the predictive factors of health behaviors together with their significance and to evaluate the magnitude of variance explained by these factors. The level of significance was $p<0.05$. The database and statistical surveys were based on the Statistica 9.1 computer software (StatSoft, Poland).

\section{Ethical requirements}

The survey was voluntary and anonymous. Each of the respondents was informed about the purpose of the 
Grzegorz J. Nowicki, Barbara Ślusarska, Ewa Rudnicka-Drożak, Anna Wiśniewska, Bernadeta Jędrzejkiewicz, Kamil Pielaszkiewicz, Aleksandra Sekut

Tab. 1. Sociodemographic characteristics of the respondents

\begin{tabular}{|c|c|c|c|}
\hline Variable & $\begin{array}{c}\text { Group M } \\
(\mathrm{N}=305) \\
{[\mathrm{n}(\%)]}\end{array}$ & $\begin{array}{c}\text { Group } P \\
(\mathrm{~N}=293) \\
{[n(\%)]}\end{array}$ & $\begin{array}{c}\text { Total } \\
(\mathrm{N}=598) \\
{[\mathrm{n}(\%)]}\end{array}$ \\
\hline \multicolumn{4}{|l|}{ Gender: } \\
\hline Female & $269(88.20)$ & $69(23.55)$ & $338(56.52)$ \\
\hline Male & $36(11.80)$ & $224(76.45)$ & $260(43.48)$ \\
\hline \multicolumn{4}{|c|}{ Age [years] : mean $( \pm S D) 36.49 \pm 7.33$} \\
\hline $20-30$ & $68(22.30)$ & $82(27.99)$ & $150(25.08)$ \\
\hline $31-40$ & $133(43.61)$ & $153(52.22)$ & $286(47.83)$ \\
\hline $41-50$ & $90(29.51)$ & $50(17.06)$ & $140(23.41)$ \\
\hline 51 and above & $14(4.58)$ & $8(2.73)$ & $22(3.68)$ \\
\hline \multicolumn{4}{|c|}{ Place of residence: } \\
\hline Rural & $102(33.44)$ & $116(39.59)$ & $218(36.45)$ \\
\hline Urban & $203(66.56)$ & $177(60.41)$ & $380(63.55)$ \\
\hline \multicolumn{4}{|l|}{ Education: } \\
\hline Vocational & - & $34(11.60)$ & $34(5.69)$ \\
\hline Secondary & $155(50.82)$ & $109(37.20)$ & $264(44.15)$ \\
\hline Bachelor's degree & $86(28.20)$ & $46(15.70)$ & $132(22.07)$ \\
\hline Master's degree & $64(20.98)$ & $104(35.49)$ & $168(28.09)$ \\
\hline \multicolumn{4}{|c|}{ Parents' education: } \\
\hline \multicolumn{4}{|l|}{ Father: } \\
\hline Vocational & $188(61.64)$ & $117(39.93)$ & $305(51.00)$ \\
\hline Secondary & $94(30.82)$ & $134(45.73)$ & $228(38.13)$ \\
\hline Higher & $23(7.54)$ & $42(14.33)$ & $65(10.87)$ \\
\hline \multicolumn{4}{|l|}{ Mother: } \\
\hline Vocational & $140(45.90)$ & $75(25.60)$ & $215(35.95)$ \\
\hline Secondary & $136(44.59)$ & $132(45.05)$ & $268(44.82)$ \\
\hline Higher & $29(9.51)$ & $86(29.35)$ & 115 (19.23) \\
\hline
\end{tabular}

Monthly net income per family member [zloty]:

\begin{tabular}{|c|c|c|c|}
\hline Below 500 & $18(5.90)$ & $17(5.80)$ & $35(5.85)$ \\
\hline $501-1000$ & $100(32.79)$ & $54(18.43)$ & $154(25.75)$ \\
\hline $1001-1500$ & $66(21.64)$ & $40(13.65)$ & $106(17.73)$ \\
\hline above 1500 & $68(22.30)$ & $125(42.66)$ & $193(32.27)$ \\
\hline I refuse to answer & $53(17.38)$ & $57(19.45)$ & $110(18.39)$ \\
\hline \multicolumn{4}{|l|}{ Smoking: } \\
\hline Yes & $75(24.59)$ & $97(33.11)$ & $172(28.76)$ \\
\hline No & $183(60.00)$ & $144(49.15)$ & $327(54.68)$ \\
\hline In the past & $47(15.41)$ & $52(17.75)$ & $99(16.56)$ \\
\hline \multicolumn{4}{|c|}{ Incidence in the mother: } \\
\hline $\begin{array}{l}\text { Cardiovascular } \\
\text { diseases }\end{array}$ & $145(47.54)$ & $79(26.96)$ & $224(37.46)$ \\
\hline Cancers & $54(17.70)$ & $60(20.48)$ & $114(19.06)$ \\
\hline \multicolumn{4}{|c|}{ Incidence in the father: } \\
\hline $\begin{array}{l}\text { Cardiovascular } \\
\text { diseases }\end{array}$ & $155(50.82)$ & $107(36.52)$ & $262(43.81)$ \\
\hline Cancers & $36(11.80)$ & $45(15.36)$ & $81(13.55)$ \\
\hline \multicolumn{4}{|c|}{ Incidence in the siblings: } \\
\hline $\begin{array}{l}\text { Cardiovascular } \\
\text { diseases }\end{array}$ & $64(20.98)$ & $45(15.36)$ & $109(18.23)$ \\
\hline Cancers & $15(4.92)$ & $13(4.44)$ & $28(4.68)$ \\
\hline
\end{tabular}

\section{The level of health behaviors in the control group}

Analysis of the data collected among the representatives of the M group allows to conclude that the general indicator of the severity of health behaviors was 80.20 $(\mathrm{SD}=11.76)$. The highest rated categories of health behaviors in group $\mathrm{M}$ were: preventive actions (21.08, $\mathrm{SD}=4.04)$. The overall rate of health behaviors in group $P$ was 72.70 ( $S D=14.77)$. Among the controls from the $\mathrm{P}$ group, the highest rated categories of health behaviors included: positive mental attitude $(19.45 ; \mathrm{SD}=4.46)$.

Controls from the $M$ group were characterized by a statistically significant higher index of the general level of health behaviors and a higher rate in individual categories compared to those from the P group $(\mathrm{p}<0.05)$. Detai -led data is presented in Table 2.

\section{Subjective variables as well as anthropometric and physiological indicators conditioning health behaviors}

The distribution of subjective (health locus of control, level of self-efficacy, state of knowledge about risk factors and prevention of cardiovascular diseases), anthropometric (BMI mean value) and physiological (systolic and diastolic blood pressure mean value) variables, as well as differences between these variables in group $\mathrm{M}$ and $\mathrm{P}$ were presented in Table 3. 
The statistical analysis showed that the subjects from group $\mathrm{M}$ were characterized by a higher level of health locus of control in the internal dimension $(p=0.035)$, higher level of knowledge about risk factors and prevention of civilization diseases $(\mathrm{p}<0.001)$, lower systolic blood pressure $(\mathrm{p}<0.001)$ and diastolic blood pressure values $(\mathrm{p}<0.001)$ as well as BMI $(\mathrm{p}<0.001)$. On the other hand, respondents from group $\mathrm{P}$ were characterized by a significantly higher level of self-efficacy $(p=0.002)$.

\section{Predictors of health behaviors in the studied M and $P$ groups}

Table 4 shows the regression model of the health behaviors variable in the $M$ group. The level of self-efficacy, the health locus of control in terms of the influence of others and the chance, age, occurrence of cardiovascular disease in the father, smoking and the level of mean systolic pressure explain $17.5 \%$ of variability in health behavior in the $\mathrm{M}$ group. The level of health behaviors increases together with the increase in the level of self-efficacy, health locus of control in the category of the influence of others, and together with age. However, the health locus of control in the chance category, the occurrence of cardiovascular disease in the father, smoking and the higher value of mean systolic blood pressure (SBP) affect the level of health behaviors.

Table 5 shows the regression model of health behaviors variable in the $\mathrm{P}$ group. The multivariate analysis shows that the level of self-efficacy, the health locus of control in the category of the influence of others and the chance, a monthly net income per a family member, the occurrence of neoplasm in siblings, smoking cigarettes, mean value of blood pressure and the level of knowledge about risk factors as well as prevention of civilization diseases explain $27.9 \%$ of the variance variable for health behavior in the studied $\mathrm{P}$ group. The analysis shows that the higher the increase in self-efficacy, health locus of control in the category of the influence of others, net income per a family member, occurrence of neoplasm in siblings and an increase in mean systolic pressure and knowledge level, the higher the evaluation level of health behaviors. On the other hand, the increase in the locus of health control in the case category and cigarette smoking result in a reduction of the health behaviors level.

\section{DISCUSSION}

Health behaviors can be studied in various areas of the human activity [5]. The presented study concerned determinants of health behaviors in individuals performing medical and non-medical professions. Healthcare employees are considered to be an important source of knowledge and pro-health motivation. Through health counseling, even in the case of a short-time contact with health professionals, and even more so by setting an example, the chances of compliance with recommendations by patients and their implementation of health-promoting behaviors are highly increased [6]. That is why the importance of leading a pro-health lifestyle by the representatives of medical professions is becoming
Tab. 3. Interchangeable subjective and anthropometric and physiological indicators conditioning health behaviors

\begin{tabular}{|l|c|c|c|c|c|}
\hline \multirow{2}{*}{ Variable } & \multicolumn{2}{|c|}{ Group M } & \multicolumn{2}{c|}{ Group P } & \multirow{2}{*}{$\begin{array}{c}\text { Test } \\
\text { statistic }\end{array}$} \\
\cline { 2 - 5 } & $\begin{array}{c}\text { M } \pm \text { SD } \\
\text { (Min.-Max.) }\end{array}$ & Median & $\begin{array}{c}\text { M } \pm \text { SD } \\
\text { (Min.-Max.) }\end{array}$ & Median & \\
\hline $\begin{array}{l}\text { MHLC } \\
\text { - internal }\end{array}$ & $\begin{array}{c}26.24 \pm 4.63 \\
10-36\end{array}$ & 27.00 & $\begin{array}{c}25.44 \pm 4.63 \\
6-36\end{array}$ & 26.00 & $\begin{array}{c}\mathrm{t}=-2.17 ; \\
\mathrm{p}=0.035\end{array}$ \\
\hline $\begin{array}{l}\text { MHLC } \\
\text { - influence } \\
\text { of others }\end{array}$ & $\begin{array}{c}19.29 \pm 5.52 \\
7-36\end{array}$ & 19.00 & $\begin{array}{c}19.98 \pm 5.48 \\
6-35\end{array}$ & 19.00 & $\begin{array}{c}\mathrm{t}=1.528 ; \\
\mathrm{p}=0.127\end{array}$ \\
\hline MHLC - chance & $\begin{array}{c}20.15 \pm 5.42 \\
7-35\end{array}$ & 20.00 & $\begin{array}{c}19.62 \pm 5.21 \\
6-36\end{array}$ & 20.00 & $\begin{array}{c}\mathrm{t}=-1.217 ; \\
\mathrm{p}=0.224\end{array}$ \\
\hline GSES & $\begin{array}{c}30.40 \pm 3.49 \\
20-30\end{array}$ & 30.00 & $\begin{array}{c}31.40 \pm 4.37 \\
11-31\end{array}$ & 32.00 & $\begin{array}{c}\mathrm{t}=3.064 ; \\
\mathrm{p}=0.002\end{array}$ \\
\hline Knowledge & $\begin{array}{c}20.45 \pm 2.58 \\
4-25\end{array}$ & 21.00 & $\begin{array}{c}17.66 \pm 3.14 \\
9-25\end{array}$ & 18.00 & $\begin{array}{c}\mathrm{t}=-11.837 ; \\
\mathrm{p}<0.001\end{array}$ \\
\hline SBP & $\begin{array}{c}118.89 \pm 10.25 \\
90-157.5\end{array}$ & 120.00 & $\begin{array}{c}123.63 \pm 8.57 \\
95-167\end{array}$ & 167.00 & $\begin{array}{c}\mathrm{t}=-6.136 ; \\
\mathrm{p}<0.001\end{array}$ \\
\hline DBP & $\begin{array}{c}77.87 \pm 8.24 \\
45-100.5\end{array}$ & 80.00 & $\begin{array}{c}81.14 \pm 8.57 \\
95-111.5\end{array}$ & 80.50 & $\begin{array}{c}\mathrm{t}=-5.016 ; \\
\mathrm{p}<0.001\end{array}$ \\
\hline BMI & $\begin{array}{c}24.33 \pm 3.94 \\
18.13-42.16\end{array}$ & 23.81 & $\begin{array}{c}26.13 \pm 4.40 \\
18.29-44.44\end{array}$ & 25.77 & $\begin{array}{c}\mathrm{t}=-5.285 ; \\
\mathrm{p}<0.001\end{array}$ \\
\hline
\end{tabular}

MHLC - health locus of control; $\quad$ GSES - level of self-efficacy; $\quad$ SBP - systolic blood pressure; DBP - diastolic blood pressure; $\quad$ BMI - body mass index M- mean; SD- standard deviation

- Tab. 4. Stepwise regression analysis of variable health behaviors in the studied group $\mathrm{M}(\mathrm{N}=305)$

\begin{tabular}{|c|c|c|c|c|}
\hline \multirow[t]{2}{*}{ Variable } & \multicolumn{4}{|c|}{$\begin{array}{l}\text { The general level of health behaviors } \\
R^{2}=0.175 ; F(7.304)=10.199 ; p<0.001\end{array}$} \\
\hline & B & $\beta$ & $t$ & $p$ \\
\hline GSES & 0.782 & 0.232 & 4.430 & $<0.001$ \\
\hline MHLC - influence of others & 0.413 & 0.194 & 3.580 & $<0.001$ \\
\hline MHLC - chance & -0.256 & 0.118 & -2.156 & 0.032 \\
\hline Age & 0.178 & 0.119 & 2.273 & 0.024 \\
\hline $\begin{array}{l}\text { The occurrence of } \\
\text { cardiovascular disease } \\
\text { in the father }\end{array}$ & -2.963 & -0.126 & -2.392 & 0.017 \\
\hline Smoking & -6.172 & -0.226 & -4.114 & $<0.001$ \\
\hline SBP & -0.165 & -0.144 & -2.730 & 0.007 \\
\hline
\end{tabular}

$R^{2}$ - the degree of fit of the model,

$\mathrm{F}, \mathrm{p}$ - $\mathrm{F}$ statistics and statistical significance level to determine if the model is statistically significant, $B$ - coefficient of the regression model,

$B, B e t a, t, p$ - analysis of the impact of individual independent variables.

Tab. 5. Stepwise regression analysis of variable health behaviors in the studied group $\mathrm{P}(\mathrm{N}=293)$

\begin{tabular}{|l|c|c|c|c|}
\hline \multirow{2}{*}{\multicolumn{1}{|c|}{ Variable }} & \multicolumn{5}{c|}{ The general level of health behaviors } \\
& $\mathbf{R}^{2}=\mathbf{0 . 2 7 9 ;} \mathbf{F}(\mathbf{8 . 2 9 2} \mathbf{= 1 5 . 1 3 7 ;} \mathbf{p}<\mathbf{0 . 0 0 1}$ \\
\cline { 2 - 5 } & $\mathbf{B}$ & $\boldsymbol{\beta}$ & $\mathbf{t}$ & $\mathbf{p}$ \\
\hline GSES & 0.384 & 0.113 & 2.112 & 0.036 \\
\hline MHLC - influence of others & 0.775 & 0.287 & 5.564 & $<0.001$ \\
\hline MHLC - chance & -0.537 & -0.190 & -3.626 & $<0.001$ \\
\hline $\begin{array}{l}\text { Monthly net income } \\
\text { per family member }\end{array}$ & 2.183 & 0.172 & 3.242 & 0.001 \\
\hline $\begin{array}{l}\text { Prevalence of tumors in } \\
\text { siblings }\end{array}$ & 11.348 & 0.159 & 2.696 & 0.007 \\
\hline Smoking & -5.082 & -0.162 & -3.150 & 0.002 \\
\hline SBP & 0.211 & 0.123 & 2.441 & 0.015 \\
\hline Knowledge & 0.145 & 0.124 & 2.307 & 0.022 \\
\hline
\end{tabular}

Signatures as in Tab. 4. 
more and more significant. In the comparative analysis, in their own studies, representatives of medical professions reached a higher level of a general rate of health behaviors as well as four categories of health behaviors in comparison with those who performed non-medical professions. Similar results were obtained by Baran et al. [7] evaluating health behaviors in medical and non-medical students. However, in the studies by Andruszkiewicz et al. [8] in the group of 43 nurses and 40 teachers using the Positive Health Behavior Scale for Women, no significant differences were found with respect to positive health behaviors. Therefore, studies on health behaviors in individuals performing medical and non-medical professions should be continued and carried out on a larger sample.

There are several factors that determine pro- and anti-health behaviors. These factors may be related to the individual (education, socioeconomic position, marital status, sense of the health locus of control, level of self-efficacy, sense of coherence), to cultural values of society (housing standard, shaped hygienic habits, culinary traditions, lifestyle, sexual and family life patterns and rest), to upbringing (creating habits directly or indirectly related to protection and improvement of health in the course of ontogenetic development) [9]. The study was to check to what extent the selected determinants affected health behaviors of individuals performing medical and non-medical professions. Multivariate analysis of regression of health behaviors revealed that the health behavior variable in the case of individuals performing medical professions was explained in $17.5 \%$ by the level of self-efficacy, the health locus of control in the categories of the influence of others and the chance, age, occurrence of cardiovascular disease in the father, smoking cigarettes and the level of mean systolic pressure. Among non-medical professionals, the level of self-efficacy, the health locus of control in the categories the influence of others and the case, a monthly net income per a family member, the occurrence of neoplasm in siblings, cigarette smoking, mean systolic pressure and knowledge explain $27.5 \%$ of the variability in health behaviors. In the studies by Zadworna-Cieślak and Ogińska-Bulik [10], in 130 individuals attending classes at the University of the Third Age, the health behavior variable (IHB) was in $14 \%$ explained by gender, health condition and optimism level (LOT-R). In the studies by Nowicki et al. [11] conducted in the group of 150 working individuals, the health behavior variable (IHB) was in $30 \%$ explained by the level of optimism (LOT-R), diet, gender and competition (Framingham type A). The increase in the level of optimism and the dietary rating increased the level of health behaviors (IHB), while male gender and competition reduced it. The results of the studies by Bąk-Sosnowska et al. [12] conducted among medical doctors showed that the occurrence of anti-health behaviors increased by $3.2 \%$ each year after the completion of specialization, by $2.6 \%$ following a decrease in the total coherence sense scale by each point in the score (SOC -29) and by $14.4 \%$ with the decrease in active coping with stress scale by each point in the score (Mini-Cope).

\section{CONCLUSIONS}

There are significant differences in selected determinants of health behaviors in the group of individuals performing medical and non-medical professions, with their stronger impact on non-medical professionals $(17.5 \%$ vs. $27.9 \%$ of their variability). Common determinants of this variability in both groups included the level of self-efficacy, the health locus of control in terms of the influence of others and the chance, as well as cigarette smoking and the value of systolic blood pressure. The other determinants in both groups were different. Health knowledge was significant only in the group of individuals representing non-medical professions.

\section{Determinanty zachowań zdrowotnych osób wykonujących zawody medyczne i pozamedyczne}

\section{WPROWADZENIE}

Utrzymanie dobrego zdrowia oraz wykrywanie jego zaburzeń determinowane jest przez zachowania zdrowotne jednostki oraz podejmowanie samodzielnych działań kontrolujących i oceniających funkcjonowanie organizmu. Zachowania zdrowotne i ich determinanty są $\mathrm{w}$ centrum zainteresowania wielu dyscyplin nauk społecznych i medycznych. Dzięki analizom empirycznym zachowań zdrowotnych i ich uwarunkowań przez pryzmat różnych dyscyplin naukowych, wynikających z odrębnego warsztatu naukowego i doświadczenia danej dyscypliny, wyniki badań i rozważania teoretyczne wnoszą nowe światło $\mathrm{w}$ wielowymiarowe postrzeganie tego zagadnienia [1].
Praca zawodowa stanowi jedną z głównych form działalności człowieka. Zakład pracy staje się doskonałym miejscem do realizacji różnych przedsięwzięć promocyjnych w sferze zdrowia zwłaszcza w zakresie zmiany zachowań antyzdrowotnych. Powiązanie zdrowia ze stylem życia wymaga udzielenia pomocy jednostce $\mathrm{w}$ zakresie modyfikowania indywidualnych wzorów zachowań oraz kształtowania prozdrowotnego stylu życia, polegającego na świadomym podejmowaniu określonych działań, które zwiększają zasoby własnego zdrowia oraz eliminują zagrożenia. Kluczową rolę w tym procesie przypisuje się determinantom zachowań zdrowotnych [2]. 


\section{CEL PRACY}

Celem pracy jest określenie determiantów zachowań zdrowotnych w grupie osób wykonujących zawody medyczne i pozamedyczne.

\section{MATERIA I METODYKA}

Badania zostały przeprowadzone od czerwca 2014 roku do marca 2015 roku. Wzięło w nich udział 598 osób czynnych zawodowo, przedstawicieli 6 zawodów, w tym 3 zawodów medycznych (grupa M) - 305 osób i 3 zawodów pozamedycznych (grupa P) - 293 osoby. Grupa M reprezentowana była przez pielęgniarki i położne $(61,97 \% ; n=189)$, opiekunów medycznych $(16,2 \% ; n=51)$ oraz techników sterylizacji medycznej $(21,31 \% ; n=65)$. W skład grupy $\mathrm{P}$ weszli: górnicy $(42,66 \% ; n=125)$, nauczyciele $(34,13 \%)$ oraz pracownicy służby więziennej $(34,13 \%$; $=100)$.

Metodą badawczą był sondaż diagnostyczny oraz wykonanie dwukrotnego pomiaru ciśnienia tętniczego krwi, wzrostu i masy ciała w celu obliczenia wskaźnika BMI. Kwestionariusz ankiety składał się z następujących narzędzi badawczych: metryczki (oceniająca dane socjo-demograficzne), Inwentarz Zachowań Zdrowotnych - IZZ (oceniającego zachowania zdrowotne w kategoriach: prawidłowe nawyki żywieniowe, zachowania profilaktyczne, praktyki zdrowotne i pozytywne nastawienie psychiczne, oraz ogólny poziom zachowań zdrowotnych), Wielowymiarowej Skali Umiejscowienia Kontroli Zdrowia -MHLC - wersja B (ujmuje przekonania dotyczące zgeneralizowanych oczekiwań w trzech wymiarach umiejscowienia kontroli zdrowia, tj.: wewnętrzne, wpływ innych oraz przypadek), Skali Uogólnionej Własnej Skuteczności - GSES (do pomiaru siły ogólnego przekonania jednostki co do skuteczności radzenia sobie $\mathrm{z}$ trudnymi sytuacjami i przeszkodami) [3] Test wiedzy (własnego autorstwa) na temat cyników ryzyka i profilaktyki chorób cywilizacyjnych obejmował 25 pytań, z czego 15 pierwszych było wspólnych dla obu płci, a 10 ostatnich pytań było różnych dla kobiet i mężczyzn. Narzędzie miało na celu ocenę poziomu wiedzy na temat ogólnopolskich programów profilaktycznych, znajomość zasad samobadania piersi i jąder oraz czynników ryzyka najczęstszych chorób cywilizacyjnych. Zastosowano test typu prawda-fałsz polegający na określeniu, czy podane stwierdzenia są prawdziwe czy fałszywe. Uzyskane odpowiedzi oceniono punktowo za poprawną odpowiedź respondent otrzymywał 1 punkt, za niepoprawną lub brak odpowiedzi - 0. Maksymalnie badany mógł uzyskać 25 punktów. Im wyższa liczba punktów, tym wyższy stan wiedzy.

Pomiaru masy ciała dokonano za pomoca wagi osobowo-lekarskiej z dokładnością do 0,1 kg. Wzrost określano za pomocą wysokościomierza z dokładnością do 0,5 $\mathrm{cm}$. Następnie wszystkim badanym obliczono wskaźnik BMI definiowany jako masa ciała w kilogramach $(\mathrm{kg})$ podzielona przez wzrost w metrach do kwadratu (kg/ $\mathrm{m}^{2}$ ) [4]. Spoczynkowy pomiar ciśnienia tętniczego krwi wykonano metodą Korotkowa. Pomiaru dokonano dwukrotnie. Posłużono się elektronicznym ciśnieniomierzem typu OMRON M1.
Uzyskane wyniki badań poddano analizie statystycznej. Wartości analizowanych parametrów mierzalnych przedstawiono przy pomocy wartości średniej, odchylenia standardowego, wartości minimalnych i maksymalnych oraz mediany, a dla niemierzalnych - przy pomocy liczności i odsetka. Rozkład analizowanych zmiennych sprawdzono przy użyciu testu Shapiro-Wilka. Do zbadania różnic w parametrach mierzalnych pomiędzy dwiema grupami zastosowano test t-Studenta. Do oceny czynników predykcyjnych zachowań zdrowotnych oraz oceny ich istotności i oszacowania wielkości wariancji wyjaśnionej przez te czynniki zastosowano krokową analizę regresji. Przyjęto poziom istotności $\mathrm{p}<0,05$. Bazę danych i badania statystyczne prowadzono w oparciu o oprogramowanie komputerowe Statistica 9.1 (StatSoft, Polska).

\section{Wymagania etyczne}

Badania były dobrowolne i anonimowe. Każdy $z$ respondentów był informowany o celu badania oraz sposobie wypełniania kwestionariusza, następnie pozyskiwano zgodę na udział w badaniu. Realizowana procedura badawcza była zgodna z Deklaracja Helsińska i otrzymała pozytywną opinię Komisji Bioetycznej przy Uniwersytecie Medycznym w Lublinie (KE-0254/281/2013).

\section{WYNIKI}

\section{Charakterystyka badanych}

Średnia wieku badanych osób wyniosła 36,49 roku $(\mathrm{SD}=7,33)$. Zarówno w grupie $\mathrm{M}(\mathrm{n}=203 ; 66,56 \%)$ jak i w $\mathrm{P}(\mathrm{n}=177 ; 60,41 \%)$ większość badanych to osoby mieszkające w mieście oraz posiadające wykształcenie średnie (grupa $\mathrm{M}-\mathrm{n}=155 ; 50,82 \%$ oraz grupa $\mathrm{P}-\mathrm{n}=109 ; 37,2 \%$ ). Pozostałe zmienne socjo-demograficzne przedstawia Tab. 1.

\section{Poziom zachowań zdrowotnych w badanej grupie}

Analiza danych zebranych wśród przedstawicieli grupy M pozwala stwierdzić, że ogólny wskaźnik nasilenia zachowań zdrowotnych wynosił 80,20 (SD = 11,76). Najwyżej ocenione kategorie zachowań zdrowotnych w grupie $M$ to: zachowania profilaktyczne $(21,08 ; \mathrm{SD}=$ 4,04). Ogólny wskaźnik zachowań zdrowotnych w grupie $\mathrm{P}$ wynosił 72,70 (SD = 14,77). Wśród osób $\mathrm{z}$ grupy $\mathrm{P}$ kategorie zachowań zdrowotnych najwyżej ocenione to: pozytywne nastawienie psychiczne $(19,45 ; \mathrm{SD}=4,46)$.

Osoby $\mathrm{z}$ grupy $\mathrm{M}$ charakteryzowały się istotnie statystycznie wyższym wskaźnikiem ogólnego poziomu zachowań zdrowotnych oraz wyższym wskaźnikiem w poszczególnych kategoriach $\mathrm{w}$ porównaniu $\mathrm{z}$ badanymi $\mathrm{z}$ grupy $\mathrm{P}$ $(\mathrm{p}<0,05)$. Szczegółowe dane przedstawia Tab. 2.

\section{Zmienne podmiotowe oraz antropometryczne i fizjologiczne jako wskaźniki warunkujące zachowania zdrowotne}

Rozkład zmienny podmiotowych (umiejscowienie kontroli zdrowia, poziom własnej skuteczności, stan wiedzy na temat czynników ryzyka i profilaktyki chorób 
Tab. 1. Charakterystyka socjodemograficzna badanych

\begin{tabular}{|c|c|c|c|}
\hline Zmienna & $\begin{array}{c}\text { Grupa M } \\
(\mathrm{N}=305) \\
{[\mathrm{n}(\%)]}\end{array}$ & $\begin{array}{c}\text { Grupa P } \\
(\mathrm{N}=293) \\
{[n(\%)]}\end{array}$ & $\begin{array}{c}\text { Razem } \\
(\mathrm{N}=598) \\
{[\mathrm{n}(\%)]}\end{array}$ \\
\hline \multicolumn{4}{|l|}{ Płeć: } \\
\hline Kobiety & $269(88,20)$ & $69(23,55)$ & $338(56,52)$ \\
\hline Mężczyźni & $36(11,80)$ & $224(76,45)$ & $260(43,48)$ \\
\hline \multicolumn{4}{|c|}{ Wiek [lata] : średnia ( \pm SD) $36,49 \pm 7,33$} \\
\hline $20-30$ & $68(22,30)$ & $82(27,99)$ & $150(25,08)$ \\
\hline $31-40$ & $133(43,61)$ & $153(52,22)$ & $286(47,83)$ \\
\hline $41-50$ & $90(29,51)$ & $50(17,06)$ & $140(23,41)$ \\
\hline 51 i powyżej & $14(4,58)$ & $8(2,73)$ & $22(3,68)$ \\
\hline \multicolumn{4}{|l|}{ Miejsce zamieszkania: } \\
\hline Wieś & $102(33,44)$ & $116(39,59)$ & $218(36,45)$ \\
\hline Miasto & $203(66,56)$ & $177(60,41)$ & $380(63,55)$ \\
\hline \multicolumn{4}{|l|}{ Wykształcenie: } \\
\hline Zawodowe & - & $34(11,60)$ & $34(5,69)$ \\
\hline Średnie & $155(50,82)$ & $109(37,20)$ & $264(44,15)$ \\
\hline Wyższe I stopnia & $86(28,20)$ & $46(15,70)$ & $132(22,07)$ \\
\hline Wyższe Il stopnia & $64(20,98)$ & $104(35,49)$ & $168(28,09)$ \\
\hline \multicolumn{4}{|c|}{ Wykształcenie rodziców: } \\
\hline \multicolumn{4}{|l|}{ 0jca: } \\
\hline Zawodowe & $188(61,64)$ & $117(39,93)$ & $305(51,00)$ \\
\hline Średnie & $94(30,82)$ & $134(45,73)$ & $228(38,13)$ \\
\hline Wyższe & $23(7,54)$ & $42(14,33)$ & $65(10,87)$ \\
\hline \multicolumn{4}{|l|}{ Matki: } \\
\hline Zawodowe & $140(45,90)$ & $75(25,60)$ & $215(35,95)$ \\
\hline Średnie & $136(44,59)$ & $132(45,05)$ & $268(44,82)$ \\
\hline Wyższe & $29(9,51)$ & $86(29,35)$ & $115(19,23)$ \\
\hline \multicolumn{4}{|c|}{ Miesięczny dochód netto na członka rodziny [złote]: } \\
\hline Poniżej 500 & $18(5,90)$ & $17(5,80)$ & $35(5,85)$ \\
\hline $501-1000$ & $100(32,79)$ & $54(18,43)$ & $154(25,75)$ \\
\hline 1001-1500 & $66(21,64)$ & $40(13,65)$ & $106(17,73)$ \\
\hline Powyżej 1500 & $68(22,30)$ & $125(42,66)$ & $193(32,27)$ \\
\hline $\begin{array}{l}\text { Odmawiam udzielenia } \\
\text { odpowiedzi }\end{array}$ & $53(17,38)$ & $57(19,45)$ & $110(18,39)$ \\
\hline \multicolumn{4}{|l|}{ Palenie papierosów: } \\
\hline Tak & $75(24,59)$ & $97(33,11)$ & $172(28,76)$ \\
\hline Nie & $183(60,00)$ & $144(49,15)$ & $327(54,68)$ \\
\hline W przeszłości & $47(15,41)$ & $52(17,75)$ & $99(16,56)$ \\
\hline \multicolumn{4}{|c|}{ Występowanie u matki: } \\
\hline chorób układu krążenia & $145(47,54)$ & $79(26,96)$ & $224(37,46)$ \\
\hline nowotworów & $54(17,70)$ & $60(20,48)$ & $114(19,06)$ \\
\hline \multicolumn{4}{|l|}{ Występowanie u ojca: } \\
\hline chorób układu krążenia & $155(50,82)$ & $107(36,52)$ & $262(43,81)$ \\
\hline nowotworów & $36(11,80)$ & $45(15,36)$ & $81(13,55)$ \\
\hline \multicolumn{4}{|c|}{ Występowanie u rodzeństwa: } \\
\hline chorób układu krążenia & $64(20,98)$ & $45(15,36)$ & $109(18,23)$ \\
\hline nowotworów & $15(4,92)$ & $13(4,44)$ & $28(4,68)$ \\
\hline
\end{tabular}

układu sercowo naczyniowego) oraz antropometrycznych (średnia wskaźnika BMI) i fizjologicznych (średnia ciśnienia skurczowego i rozkurczowego krwi), a także różnice pomiędzy tymi zmiennymi w grupie M i P przedstawiono w Tab. 3.

Przeprowadzona analiza statystyczna wykazała, że badani z grupy M charakteryzowali się większym poziomem umiejscowienia kontroli zdrowia $\mathrm{w}$ wymiarze wewnętrznym $(\mathrm{p}=0,035)$, wyższym poziomem wiedzy na temat czynników ryzyka i profilaktyki chorób cywilizacyjnych $(\mathrm{p}<0,001)$ oraz niższymi wartościami ciśnienia skurczowego $(\mathrm{p}<0,001)$, rozkurczowego $(\mathrm{p}<0,001)$ i wskaźnikiem BMI $(\mathrm{p}<0,001)$. Natomiast respondenci $\mathrm{z}$ grupy $\mathrm{P}$ charakteryzowali się istotnie wyższym poziomem własnej skuteczności $(p=0,002)$.

Tab. 2. Zachowania zdrowotne w badanej grupie M i P

\begin{tabular}{|c|c|c|c|c|c|}
\hline \multirow[b]{2}{*}{ Zmienna } & \multicolumn{2}{|c|}{ Grupa M } & \multicolumn{2}{|c|}{ Grupa P } & \multirow{2}{*}{$\begin{array}{c}\text { Analiza } \\
\text { statystycna }\end{array}$} \\
\hline & $\begin{array}{c}\text { M } \pm \text { SD } \\
\text { (Min.-Maks.) }\end{array}$ & Mediana & $\begin{array}{c}\text { M } \pm \text { SD } \\
\text { (Min.-Maks.) }\end{array}$ & Mediana & \\
\hline $\begin{array}{l}\text { Prawidłowe } \\
\text { nawyki } \\
\text { żywieniowe }\end{array}$ & $\begin{array}{c}20,14 \pm 4,11 \\
(10-30)\end{array}$ & 20,00 & $\begin{array}{c}17,81 \pm 4,78 \\
(6-30)\end{array}$ & 18,00 & $\begin{array}{l}t=-6,383 \\
p<0,001\end{array}$ \\
\hline $\begin{array}{l}\text { Zachowania } \\
\text { profilaktyczne }\end{array}$ & $\begin{array}{c}21,08 \pm 4,04 \\
(8-30)\end{array}$ & 22,00 & $\begin{array}{c}18,15 \pm 4,65 \\
(6-29)\end{array}$ & 18,00 & $\begin{array}{l}t=-8,216 \\
p<0,001\end{array}$ \\
\hline $\begin{array}{l}\text { Pozytywne } \\
\text { nastawienie } \\
\text { psychiczne }\end{array}$ & $\begin{array}{c}20,86 \pm 3,62 \\
(11-30)\end{array}$ & 21,00 & $\begin{array}{c}19,45 \pm 4,46 \\
(6-28)\end{array}$ & 20,00 & $\begin{array}{l}t=-4,228 \\
\mathrm{p}<0,001\end{array}$ \\
\hline $\begin{array}{l}\text { Praktyki } \\
\text { zdrowotne }\end{array}$ & $\begin{array}{c}18,13 \pm 3,88 \\
(9-30) \\
\end{array}$ & 18,00 & $\begin{array}{c}17,29 \pm 4,26 \\
(6-27)\end{array}$ & 18,00 & $\begin{array}{l}t=-2,526 \\
p=0,028\end{array}$ \\
\hline $\begin{array}{l}\text { Ogólny } \\
\text { wskaźnik } \\
\text { nasilenia } \\
\text { zachowań } \\
\text { zdrowotnych } \\
\text { (suma) }\end{array}$ & $\begin{array}{c}80,20 \pm 11,76 \\
(49-118)\end{array}$ & 80,00 & $\begin{array}{c}72,70 \pm 14,77 \\
(24-106)\end{array}$ & 74,00 & $\begin{array}{l}t=-6,856 \\
p<0,001\end{array}$ \\
\hline
\end{tabular}

$M($ mean) - średnia, SD - odchylenie standardowe

Tab. 3. Zamienne podmiotowe oraz antropometryczne i fizjologiczne wskaźniki warunkujące zachowania zdrowotne

\begin{tabular}{|l|c|c|c|c|c|}
\hline \multirow{2}{*}{ Zmienna } & \multicolumn{2}{|c|}{ Grupa M } & \multicolumn{2}{c|}{ Grupa P } & Analiza \\
\cline { 2 - 5 } & $\begin{array}{c}\text { M } \pm \text { SD } \\
\text { (Min.-Maks.) }\end{array}$ & Mediana & $\begin{array}{c}\text { M } \pm \text { SD } \\
\text { (Min.-Maks.) }\end{array}$ & Mediana & statystycna \\
\hline $\begin{array}{l}\text { MHLC } \\
\text { wewnętrzne }\end{array}$ & $\begin{array}{c}26,24 \pm 4,63 \\
10-36\end{array}$ & 27,00 & $\begin{array}{c}25,44 \pm 4,63 \\
6-36\end{array}$ & 26,00 & $\begin{array}{c}\mathrm{t}=-2,17 ; \\
\mathrm{p}=0,035\end{array}$ \\
\hline $\begin{array}{l}\text { MHLC wpływ } \\
\text { innych }\end{array}$ & $\begin{array}{c}19,29 \pm 5,52 \\
7-36\end{array}$ & 19,00 & $\begin{array}{c}19,98 \pm 5,48 \\
6-35\end{array}$ & 19,00 & $\begin{array}{c}\mathrm{t}=1,528 ; \\
\mathrm{p}=0,127\end{array}$ \\
\hline $\begin{array}{l}\text { MHLC } \\
\text { przypadek }\end{array}$ & $\begin{array}{c}20,15 \pm 5,42 \\
7-35\end{array}$ & 20,00 & $\begin{array}{c}19,62 \pm 5,21 \\
6-36\end{array}$ & 20,00 & $\begin{array}{c}\mathrm{t}=-1,217 ; \\
\mathrm{p}=0,224\end{array}$ \\
\hline GSES- suma & $\begin{array}{c}30,40 \pm 3,49 \\
20-30\end{array}$ & 30,00 & $\begin{array}{c}31,40 \pm 4,37 \\
11-31\end{array}$ & 32,00 & $\begin{array}{c}\mathrm{t}=3,064 ; \\
\mathrm{p}=0,002\end{array}$ \\
\hline Stan wiedzy & $\begin{array}{c}20,45 \pm 2,58 \\
4-25\end{array}$ & 21,00 & $\begin{array}{c}17,66 \pm 3,14 \\
9-25\end{array}$ & 18,00 & $\begin{array}{c}\mathrm{t}=-11,837 ; \\
\mathrm{p}<0,001\end{array}$ \\
\hline SBP & $\begin{array}{c}118,89 \pm 10,25 \\
90-157.5\end{array}$ & 120,00 & $\begin{array}{c}123,63 \pm 8,57 \\
95-167\end{array}$ & 167,00 & $\begin{array}{c}\mathrm{t}=-6,136 ; \\
\mathrm{p}<0,001\end{array}$ \\
\hline DBP & $\begin{array}{c}77,87 \pm 8,24 \\
45-100,5\end{array}$ & 80,00 & $\begin{array}{c}81,14 \pm 8,57 \\
95-111,5\end{array}$ & 80,50 & $\begin{array}{c}\mathrm{t}=-5,016 ; \\
\mathrm{p}<0,001\end{array}$ \\
\hline BMI & $\begin{array}{c}24,33 \pm 3,94 \\
18,13-42,16\end{array}$ & 23,81 & $\begin{array}{c}26,13 \pm 4,40 \\
18,29-44,44\end{array}$ & 25,77 & $\begin{array}{c}\mathrm{t}=-5,285 ; \\
\mathrm{p}<0,001\end{array}$ \\
\hline
\end{tabular}

M(mean) - średnia, SD-odchylenie standardowe 


\section{Predykatory zachowań zdrowotnych w badanej grupie M i P}

Tab. 4 przedstawia model regresji zmiennej zachowań zdrowotnych w grupie M. Poziom własnej skuteczności, umiejscowienie kontroli zdrowia w kategoriach wpływ innych i przypadek, wiek, występowanie chorób układu krążenia u ojca, palenie papierosów oraz poziom średniego ciśnienia skurczowego wyjaśniają 17,5\% zmienności zachowania zdrowotnego w grupie M. Wraz ze wzrostem poziomu własnej skuteczności, umiejscowienia kontroli zdrowia w kategorii wpływ innych oraz wraz z wiekiem zwiększa się poziom zachowań zdrowotnych. Natomiast umiejscowienie kontroli zdrowia w kategorii przypadek, występowanie chorób układu krążenia u ojca, palenie tytoniu oraz większa wartość średniego ciśnienia skurczowego (SBP) wpływają na obniżenie poziomu zachowań zdrowotnych.

Tab. 5 przedstawia model regresji zmiennej zachowań zdrowotnych w grupie P. Z przeprowadzonej analizy wieloczynnikowej wynika, że poziom własnej skuteczności, umiejscowienie kontroli zdrowia w kategorii wpływ innych i przypadek, miesięczny dochód netto na członka rodziny, występowanie nowotworów u rodzeństwa, palenie papierosów, średnia wartość ciśnienia tętniczego krwi oraz poziom wiedzy o czynnikach ryzyka i profilaktyce chorób cywilizacyjnych wyjaśniają 27,9\% wariancji zmiennej zachowania zdrowotne w badanej grupie P. Z analizy wynika, że wraz ze wzrostem poziomu własnej skuteczności, umiejscowienia kontroli zdrowia w kategorii wpływ innych, dochodu netto na członka rodziny, z występowaniem choroby nowotworowej u rodzeństwa oraz wzrostem średniego ciśnienia skurczowego i poziomu wiedzy wzrasta ocena poziomu zachowań zdrowotnych. Natomiast wzrost umiejscowienia kontroli zdrowia w kategorii przypadek oraz palenie papierosów powodują zmniejszenie poziomu zachowań zdrowotnych.

\section{DYSKUSJA}

Zachowania zdrowotne mogą być badane w różnych obszarach aktywności człowieka [5]. Przedstawione badania dotyczyły determinantów zachowań zdrowotnych osób wykonujących zawody medyczne i pozamedyczne. Za ważne źródło wiedzy i motywacji zdrowotnej uważa się pracowników ochrony zdrowia. Poprzez porady zdrowotne nawet w przypadku krótkiego kontaktu z przedstawicielami zawodów medycznych a tym bardziej poprzez przykład, zwiększane są szanse na stosowanie się pacjentów do zaleceń i wprowadzanie w życie zachowań sprzyjających zdrowiu [6]. Dlatego też znaczenia nabiera fakt prowadzenia prozdrowotnego stylu życia przez przedstawicieli zawodów medycznych. W analizie porównawczej, w badaniach własnych, osoby wykonujące zawody medyczne uzyskały wyższy poziom ogólnego wskaźnika zachowań zdrowotnych oraz czterech kategorii zachowań zdrowotnych w porównaniu $\mathrm{z}$ badanymi wykonującymi zawody pozamedyczne. Podobne wyniki uzyskali Baran i wsp. [7] oceniające zachowania zdrowotne studentów kierunków medycznych i niemedycznych. Natomiast w badaniach Andruszkiewicz i wsp. [8] w grupie 43 pielęgniarek
Tab. 4. Krokowa analiza regresji zmiennej zachowania zdrowotne w badanej grupie $\mathrm{M}(\mathrm{N}=305)$

\begin{tabular}{|c|c|c|c|c|}
\hline \multirow[t]{2}{*}{ Zmienne } & \multicolumn{4}{|c|}{$\begin{array}{l}\text { Ogólny poziom zachowań zdrowotnych } \\
R^{2}=0,175 ; F(7,304)=10,199 ; p<0,001\end{array}$} \\
\hline & B & $\beta$ & $\mathbf{t}$ & $\mathbf{p}$ \\
\hline GSES (suma) & 0,782 & 0,232 & 4,430 & $<0,001$ \\
\hline MHLC - wpływ innych & 0,413 & 0,194 & 3,580 & $<0,001$ \\
\hline MHLC - przypadek & $-0,256$ & 0,118 & $-2,156$ & 0,032 \\
\hline Wiek & 0,178 & 0,119 & 2,273 & 0,024 \\
\hline $\begin{array}{l}\text { Występowanie chorób } \\
\text { układu krążenia u ojca }\end{array}$ & $-2,963$ & $-0,126$ & $-2,392$ & 0,017 \\
\hline Palenie papierosów & $-6,172$ & $-0,226$ & $-4,114$ & $<0,001$ \\
\hline SBP & $-0,165$ & $-0,144$ & $-2,730$ & 0,007 \\
\hline
\end{tabular}

$\mathrm{R}^{2}$ - stopień dopasowania modelu,

F, p - statystyka Fi poziom istotności statystycznej pozwalający określić, czy model jest istotny statystycznie, $B$ - współczynnik modelu regresji,

$B$, Beta, t, p - analiza wpływu poszzzególnych zmiennych niezależnych.

Tab. 5. Krokowa analiza regresji zmiennej zachowania zdrowotne w badanej grupie $\mathrm{P}(\mathrm{N}=293)$

\begin{tabular}{|c|c|c|c|c|}
\hline \multirow[t]{2}{*}{ Zmienne } & \multicolumn{4}{|c|}{$\begin{array}{l}\text { Ogólny poziom zachowań zdrowotnych } \\
R^{2}=0,279 ; F(8,292)=15,137 ; p<0,001\end{array}$} \\
\hline & B & $\beta$ & $\mathbf{t}$ & p \\
\hline GSES (suma) & 0,384 & 0,113 & 2,112 & 0,036 \\
\hline MHLC - wpływ innych & 0,775 & 0,287 & 5,564 & $<0,001$ \\
\hline MHLC - przypadek & $-0,537$ & $-0,190$ & $-3,626$ & $<0,001$ \\
\hline $\begin{array}{l}\text { Dochód netto na członka } \\
\text { rodziny }\end{array}$ & 2,183 & 0,172 & 3,242 & 0,001 \\
\hline $\begin{array}{l}\text { Występowanie } \\
\text { nowotworów u rodzeństwa }\end{array}$ & 11,348 & 0,159 & 2,696 & 0,007 \\
\hline Palenie papierosów & $-5,082$ & $-0,162$ & $-3,150$ & 0,002 \\
\hline SBP & 0,211 & 0,123 & 2,441 & 0,015 \\
\hline Poziom wiedzy & 0,145 & 0,124 & 2,307 & 0,022 \\
\hline
\end{tabular}

Podpisy jak w Tab. 4.

i 40 nauczycielek przy użyciu Skali Pozytywnych Zachowań dla Kobiet nie stwierdzono istotnych różnic w zakresie pozytywnych zachowań zdrowotnych. Dlatego też badania nad zachowaniami zdrowotnymi osób wykonujących zawody medyczne i niemedyczne powinny być kontynuowane i przeprowadzone na większej próbie.

Wyróżnić można szereg czynników determinujących podejmowanie zachowań pro i anty zdrowotnych. Czynniki te mogą być: związane z jednostką (wykształcenie, pozycja społecznoekonomiczna, stan cywilny, poczucie umiejscowienia kontroli zdrowia, poziom własnej skuteczności, poczucie koherencji), związane z kulturowymi wartościami społeczeństwa (standard mieszkaniowy, ukształtowane nawyki higieniczne, tradycje kulinarne, tryb życia, wzory życia seksualnego i rodzinnego, wypoczynek), związane $\mathrm{z}$ wychowaniem (tworzenie nawyków bezpośrednio lub pośrednio związanych $\mathrm{z}$ ochroną i doskonaleniem zdrowia w toku ontogenetycznego rozwoju) [9]. W pracy postanowiono sprawdzić, jak wybrane determinanty wpływaja na zachowania zdrowotne osób wykonujących zawody medyczne i pozamedyczne. Wieloczynnikowa analiza regresji zachowań zdrowotnych ujawniła, że zmienna zachowania zdrowotne w przypadku osób wykonujących zawód medyczny w 17,5\% jest wyjaśniona 
przez poziom własnej skuteczności, umiejscowienie kontroli zdrowia w kategoriach wpływ innych i przypadek, wiek, występowanie chorób układu krążenia ze strony ojca, palenie papierosów oraz poziom średniego ciśnienia skurczowego. Wśród przedstawicieli zawodów niemedycznych poziom własnej skuteczności, umiejscowienie kontroli zdrowia w kategoriach wpływ innych i przypadek, miesięczny dochód netto na członka rodziny, występowanie nowotworów u rodzeństwa, palenie papierosów, średnia wartość ciśnienia skurczowego oraz poziom wiedzy wyjaśniają 27,5\% zmienności podejmowania zachowań zdrowotnych. W badaniach Zadwornej-Cieślak i Ogińskiej-Bulik [10] wśród 130 osób uczęszczających na zajęcia w Uniwersytecie Trzeciego Wieku zmienna zachowania zdrowotne (IZZ) była w 14\% wyjaśniana przez płeć, stan zdrowia oraz poziom optymizmu (LOT-R). Natomiast w badaniach Nowickiego i wsp. [11] przeprowadzonych w grupie 150 osób pracujących zmienna zachowania zdrowotne (IZZ) była w 30\% wyjaśniona przez poziom optymizmu (LOT-R), ocenę jadłospisu, płeć i rywalizację (Framingham typ A). Wzrost poziomu optymizmu oraz oceny jadłospisu podwyższał poziom zachowań zdrowotnych (IZZ), natomiast płeć męska i rywalizacja obniżały go. Wyniki badań Bąk-Sosnowskiej i wsp. [12] przeprowadzonych wśród lekarzy medycyny wykazano, że występowanie zachowań antyzdrowotnych rośnie o 3,2\% z każdym rokiem od ukończenia specjalizacji, 2,6\% ze zmniejszeniem się o każdy punkt wyniku skali poczucia koherencji (SOC-29) oraz o 14,4\% wraz ze zmniejszeniem się o każdy punkt wyniku skali aktywnego radzenia sobie ze stresem (Mini-Cope).

\section{WNIOSKI}

Istnieją znaczące różnice $\mathrm{w}$ wybranych determinantach zachowań zdrowotnych w grupie osób wykonujących zawody medyczne i pozamedyczne, $z$ silniejszym ich wpływem dla osób pracujących w zawodach pozamedycznych (17,5\% vs. $27,9 \%$ ich zmienności). Wspólne determinanty tej zmienności w obu grupach obejmowały poziom własnej skuteczności, umiejscowienie kontroli zdrowia w kategoriach wpływ innych i przypadek oraz palenie papierosów i wartości ciśnienia skurczowego krwi. Pozostałe determinanty w obu grupach kształtowały się odmiennie. Wiedza o zdrowiu miała istotne znaczenie tylko w grupie osób reprezentujących zawody pozamedyczne.

\section{PIŚMIENNICTWO/REFERENCES}

1. Gruszczyńska M, Bąk-Sosnowska M, Plinta R. Zachowania zdrowotne jako istotny element aktywności życiowej człowieka. Stosunek Polaków do własnego zdrowia. Hygeia Public Health. 2015;50 (4): 558-565.

2. Nowicki GJ, Ślusarska B, Zboina B, Deluga A. Poczucie własnej skuteczności i umiejscowienie kontroli jako zasoby determinujące zachowania związane ze zdrowiem. ASO.A. 2017;10 (2):18-37.

3. Juczyński Z. Narzędzia pomiaru w promocji i psychologii zdrowia. Warszawa: PTP; 2012.

4. World Health Organisation (1995) Physical status: the use an interpretation of anthropometry: report of a WHO expert committee. Geneva: WHO Tech Rep Ser 854, pp 1-452.

5. Duda-Zalewska A. Zachowania zdrowotne nauczycieli a staż pracy w zawodzie. Hygeia Publick Health. 2012;47 (2):183-187.

6. Nowicki M, Dokurno U, Cymerys M, i wsp. Czy osoby pracujące w ochronie zdrowia dbają 0 swoje zdrowie? Badania porównawcze lekarzy i osób z niemedycznym wykształceniem wyższym. Zdr Pub. 2009;119 (2):167-170.

7. Baran A, Stocka A. Kierunek studiów jako wyznacznik zachowań zdrowotnych. Prz Med Uniw Rzesz Inst Leków. 2008; 4: 426-331.

8. Andruszkiewicz A, Nowik M. Zachowania zdrowotne kobiet czynnych zawodowo. Probl Pielęg. 2011; 19(2): 148-152.

9. Skommer M. Uwarunkowania zachowań zdrowotnych człowieka. [w:] G. Bartkowiak red. Czynniki kształtujące zachowania zdrowotne człowieka na przestrzeni życia. Nauka i praktyka. Poznań: Wyd. Naukowe Uniwersytetu Medycznego im. Karola Marcinkowskiego w Poznaniu; 2008, s. 11-30.

10. Zadworna-Cieślak M, Ogińska-Bulik N. Zachowania zdrowotne osób w wieku senioralnym - rola optymizmu. Psychogeriatria Polska. 2013;10 (4):145-156.

11. Nowicki G, Ślusarska B, Kulik TB, Goniewicz M. Czynniki psychospołeczne a wzór zachowań typu A oraz zachowania zdrowotne w prewencji ryzyka sercowonaczyniowego wśród osób dorosłych. Pol Prz Kardiol. 2011;13 (2): 82-84.

12. Bąk-Sosonowska M, Kołodziej S, Gojdź K, Skrzypulec-Plinta V. Podmiotowe czynniki ryzyka zachowań antyzdrowotnych w grupie lekarzy medycyny. Med Środow. 2015;18 (3):17-24.

Manuscript received/Praca zgłoszona do czasopisma: 15.06.2018

Manuscript accepted/Praca zaakceptowana do druku: 21.08.2018

Translation/Tłumaczenie: Beata Chrust 